\title{
TRAGIC NOISE AND RHETORICAL FRIGIDITY IN LYCOPHRON'S ALEXANDRA*
}

\begin{abstract}
This paper seeks to shed fresh light on the aesthetic and stylistic affiliations of Lycophron's Alexandra, approaching the poem from two distinct but complementary angles. First, it explores what can be gained by reading Lycophron's poem against the backdrop of Callimachus' poetry. It contends that the Alexandra presents a radical and polemical departure from the Alexandrian's poetic programme, pointedly appropriating key Callimachean images while also countering Callimachus' apparent dismissal of the 'noisy' tragic genre. Previous scholarship has noted links between the openings of the Aetia and of the Alexandra, but this article demonstrates that this relationship is only one part of a larger aesthetic divide between the two poets: by embracing the raucous acoustics of tragedy, Lycophron's poem offers a self-conscious and agonistic departure from Callimachus' aesthetic preferences. Second, this article considers another way of conceiving the aesthetics of the poem beyond a Callimachean frame, highlighting how Lycophron pointedly engages with and evokes earlier Aristotelian literary criticism concerning the 'frigid' style: the Alexandra constructs its own independent literary history centred around the alleged name of its author, 'Lycophron'. The article proposes that this traditional attribution is best understood as a pen name that signposts the poem's stylistic affiliations, aligning it not so much with the Ptolemaic playwright Lycophron of Chalcis but rather with Lycophron the sophist and a larger rhetorical tradition of stylistic frigidity. Ultimately, through these two approaches, the article highlights further aspects of the Alexandra's aesthetic diversity.
\end{abstract}

Keywords: aesthetics; Alexandra; Aristotle; Callimachus; frigidity; Lycophron; tragedy; style

In this paper, we seek to shed fresh light on the aesthetic and stylistic affiliations of Lycophron's Alexandra, a unique poetic creation. ${ }^{1}$ In 1,474 verses of iambic trimeter, an unnamed Trojan guard relays to King Priam a lengthy prophetic speech by his daughter Cassandra. Framed by the guard's own programmatic reflections (Alex. 1-30, 146174), the reported speech spans vast swathes of history and time, ranging from the Trojan War to the Roman defeat of Macedon in 197 B.c.E. The poem is, in effect, a tragic messenger speech writ large, generically experimental in its combination of drama and epic,

\footnotetext{
* We would like to thank those who offered generous feedback on draft versions of this paper: Simon Hornblower, Richard Hunter, Max Leventhal, Alan Woolley and CQ's anonymous referee.

${ }^{1}$ Following common practice, we refer to the author of the poem as Lycophron throughout, and we draw text from S. Hornblower, Lykophron: Alexandra (Oxford, 2015); translations are our own. The following publications are referred to by authors alone: C. Cusset and É. Prioux (edd.), Lycophron: éclats d'obscurité (Saint-Étienne, 2009); C. McNelis and A. Sens, The Alexandra of Lycophron: A Literary Study (Oxford, 2016).
} 
and extremely self-conscious in its manipulation of truth, voice and literary authority. Despite much excellent recent work on the poem, however, it remains remarkably difficult to pin the Alexandra down within traditional frameworks of literary interpretation. While some scholars have attempted to situate the poem against Lycophron's Hellenistic contemporaries, ${ }^{2}$ others have turned as far afield as Late European Romanticism in their hunt for a fitting analogue. ${ }^{3}$ In this paper, we wish to build on such efforts by approaching the Alexandra from two distinct but complementary angles, which will together enhance our understanding of the poem's protean style.

There is a growing communis opinio - to which we subscribe-that the Alexandra should be dated to the early second century B.C.E., at a time when Roman power was on the rise. ${ }^{4}$ One result of this down-dating is that the poem cannot have been composed by the famous Lycophron of Chalcis to which it is ascribed. Another is that it is firmly rooted in a post-Callimachean world. These two observations form the background of our two approaches to the poem.

First, we explore what can be gained by reading Lycophron's poem against the backdrop of Callimachus' poetry. We contend that the Alexandra presents a radical and polemical departure from the Alexandrian's poetic programme, pointedly appropriating key Callimachean images, while also countering Callimachus' apparent dismissal of the 'noisy' tragic genre. Previous scholarship has noted links between the openings of the Aetia and the Alexandra, but we contend that this relationship is only one part of a larger aesthetic divide between the two poets: by embracing the raucous acoustics of tragedy, Lycophron's poem offers a self-conscious and agonistic departure from Callimachus' aesthetic preferences.

Second, we consider another way of conceiving the aesthetics of the poem beyond a Callimachean frame, highlighting how Lycophron pointedly engages with and evokes earlier Aristotelian literary criticism concerning the 'frigid' style. We contend that the Alexandra constructs its own independent literary history, centred around the alleged name of its author, 'Lycophron'. We suggest that this traditional attribution is best understood as a pen name that signposts the poem's stylistic affiliations, aligning it not so much with the Ptolemaic playwright Lycophron of Chalcis but rather with a larger rhetorical tradition of stylistic frigidity. Ultimately, through these two approaches we hope to highlight further aspects of the Alexandra's aesthetic diversity.

\section{THE POETICS OF POST-CALLIMACHEAN TRAGEDY}

Recent scholarship has established a secure connection between Callimachus and Lycophron, based primarily on the latter's engagement with rare Callimachean vocabulary. ${ }^{5}$ But this relationship can be extended further to the sphere of poetics. In particular,

${ }^{2}$ Y. Durbec, Lycophron et ses contemporains (Amsterdam, 2014).

${ }^{3}$ E. Sistakou, The Aesthetics of Darkness: A Study of Hellenistic Romanticism in Apollonius, Lycophron and Nicander (Leuven, 2012), 131-90.

4 e.g. K.R. Jones, 'Lycophron's Alexandra, the Romans and Antiochus III', JHS 134 (2014), 4155; Hornblower (n. 1), 36-9; McNelis and Sens, 10-11. The major rival theories are (i) a third-century dating (e.g. A. Hurst, Sur Lycophron [Geneva, 2012], 15-22); (ii) a third-century core with later interpolations (e.g. S.R. West, 'Lycophron Italicised', JHS 104 [1984], 127-51).

5 A.S. Hollis, 'Some poetic connections of Lycophron's Alexandra', in P.J. Finglass et al. (edd.), Hesperos: Studies in Ancient Greek Poetry Presented to M.L. West on his Seventieth Birthday (Oxford, 2007), 276-93, especially 283-8; Hornblower (n. 1), 27-31. 
the opening of the Alexandra resonates pointedly against Callimachus' poetic programme (Alex. 1-15):

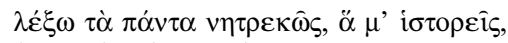

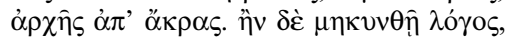

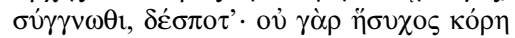

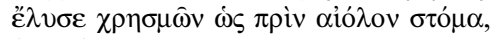

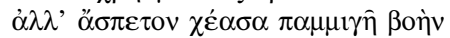

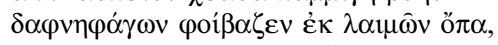

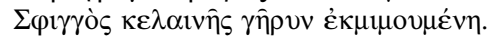

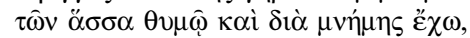

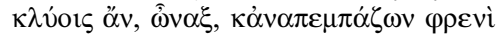

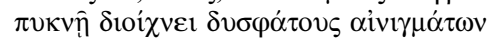

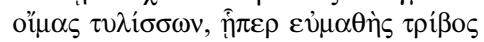

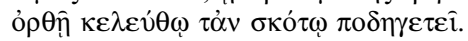

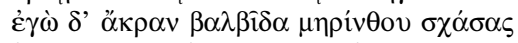

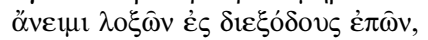

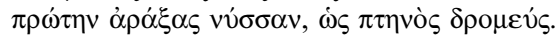

Unerringly shall I tell you everything which you ask me, from the very beginning. But if the account is long, forgive me, master. For the girl did not loose the ever-changing utterance of her oracles quietly as before, but poured forth an immense all-mixed shout, uttering the voice of Phoebus from her bay-chewing throat in imitation of the speech of the dark Sphinx. Listen, my lord, to all of it which I retain in my heart and memory, going back over it with your shrewd mind; traverse and unravel the inexplicable paths of her riddles, where a clear track leads by a straight road through what lies in darkness. As for me, now that I have broken through the starting rope, I advance into the passages of her obscure words, hitting the startingpost like a winged runner.

This programmatic opening intersects with the famous prologue of Callimachus' Aetia (fr. 1 Harder) on both verbal and thematic levels. ${ }^{6}$ To start, we can list the parallels that scholars have previously identified: both prologues are concerned with learning ( $\varepsilon \dot{u} \mu \alpha \theta \dot{\xi} \zeta$,

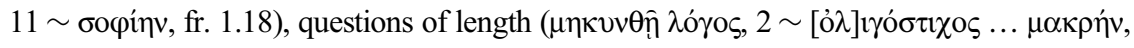

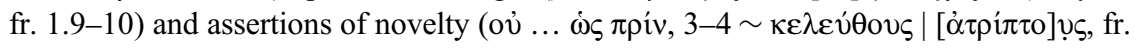

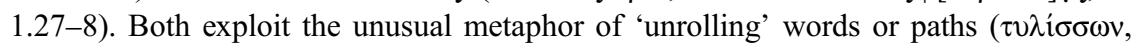
$11 \sim \dot{\varepsilon} \lambda[i \sigma \sigma \omega]$, fr. 1.5). ${ }^{7}$ And in both, the speaker likens himself to a winged figure: the messenger to a runner, Callimachus to a cicada ( $\dot{\varepsilon} \gamma \grave{\omega} \delta$ ' .. $\pi \tau \eta v$ ó $\zeta, 13-15 \sim[\dot{\varepsilon} \gamma] \grave{\omega}$

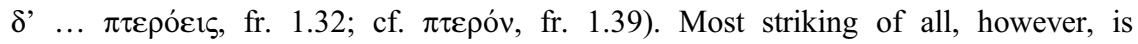
Lycophron's apparent rewriting of Callimachus' path imagery from the prologue (Aet. fr. 1.25-8):

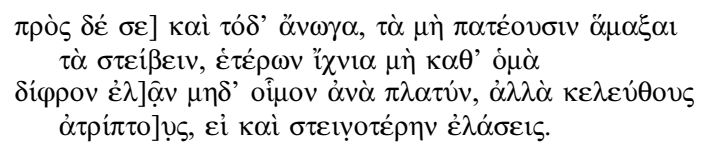

This too I bid you: tread a path which wagons do not trample; do not drive your chariot over the common tracks of others, nor along a wide road, but rather on untrodden paths, even if it means driving a narrower course.

\footnotetext{
${ }^{6} \mathrm{Cf}$. Y. Durbec, 'Lycophron et la poétique de Callimaque: le prologue de l'Alexandra, 1-15', ARF 8 (2006), 81-84; id. (n. 2), 24-35; McNelis and Sens, 63-6.

${ }^{7}$ Cf. A.R. Looijenga, 'Unrolling the Alexandra: the allusive messenger-speech of Lycophron's prologue and epilogue', in Cusset and Prioux, 59-80, at 72-3, following Hunt's supplement.
} 
Just as Apollo instructs Callimachus to pursue a specific kind of path, so too does the Lycophronic guard instruct Priam to pursue Cassandra's path of riddles (9-12). We shall consider the significance of this parallel shortly, but for now we should simply acknowledge the sheer abundance of Lycophron's hodological imagery, which precisely echoes the language of Callimachus' proem. ${ }^{8}$

Taken together, this list of parallels suggests a significant relationship between these two passages, especially given their shared introductory and programmatic contexts. Scholars, however, have disagreed about what to make of these connections. Some suppose that they simply reflect independent engagement with broader trends of the literary tradition. ${ }^{9}$ But in our view this conclusion is too cautious, since it fails to account for the underlying stylistic contrasts at play. Many details of the messenger's prologue diverge dramatically from the Callimachean course in such a way as to suggest a consistent aesthetic strategy. ${ }^{10}$ The guard's promise to tell 'everything accurately from the very beginning' (1-2; cf. ' $\dot{\alpha}$ ' $\dot{\alpha} \rho \chi \bar{\eta} \varsigma, 30)$ implies a systematic and sequential narrative akin to the

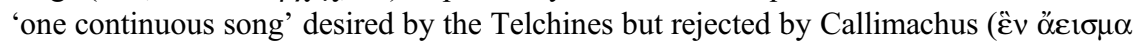

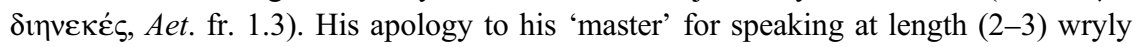
acknowledges his departure from Callimachus' stated preference for brevity. ${ }^{11}$ And his recalibration of Callimachus' path imagery further suggests an aesthetic rebranding: in place of the Callimachean untrodden paths of novelty, we are asked to navigate the

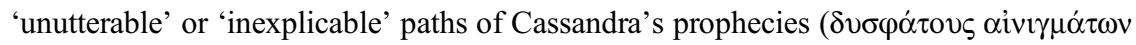

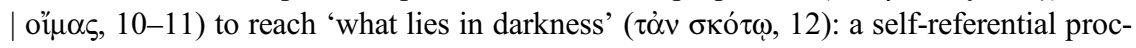
lamation of the poem's obscure and challenging style. ${ }^{12}$

Such stylistic departure from Callimachus is also visible in the opening verses' rewriting of a passage from the Aeschylean Prometheus Vinctus (609-10):

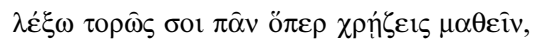

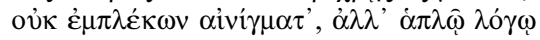

I shall tell you clearly everything that you wish to learn, not interweaving riddles, but in plain language.

In the drama, Prometheus promises to speak plainly to Io, avoiding the $\alpha i v i \gamma \mu \alpha \tau \alpha$ that

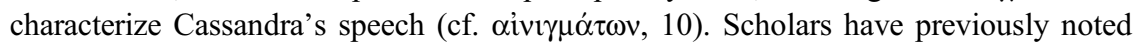
how this opening allusion advertises Lycophron's Aeschylean affiliation, while also defining the Alexandra's style implicitly through contrast: unlike Prometheus' prophecy,

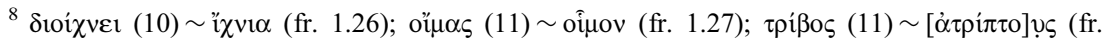

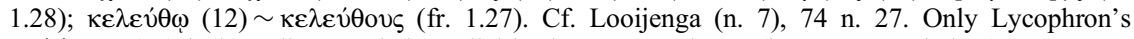
$\delta ı \xi$ ódovৎ (14) lacks a direct verbal parallel in the Aetia prologue (but see n. 32 below).

9 A. Sens, 'Hellenistic tragedy and Lycophron's Alexandra', in J.J. Clauss and M. Cuypers (edd.), A Companion to Hellenistic Literature (Oxford, 2010), 297-313, at 308; McNelis and Sens, 64.

${ }^{10}$ We thus find ourselves in closer agreement with Durbec (n. 2), 24-35, although he nevertheless fails to articulate clearly the relationship that he envisions between Callimachus and Lycophron: at times, he seems to suggest affiliation rather than distance: e.g. at 33-5 on their similar totalizing world views.

${ }^{11}$ Cf. Durbec (n. 6). $\delta \varepsilon ́ \sigma \pi o \tau '$ ' (3) strictly refers to Priam, but on a metapoetic level it could also refer to Lycophron's literary 'master', Callimachus, to whom he almost apologizes directly; Lycophron may then invert Callimachus' self-depiction as a $\pi \alpha i \varsigma$ in the Aetia prologue: not only 'child' but also 'slave' (LSJ s.v. III).

12 The paths of Cassandra's song may even become labyrinthine: her mouth is aiónov (4), a close synonym of $\delta \alpha i \delta \alpha \lambda o \varsigma$ (evoking Daedalus, the creator of the labyrinth); and the guard tells Priam to 'unravel' her path ( $\tau 0 \lambda$ i $\sigma \sigma \omega v$, a verb used of winding a ball of wool [schol. Od. 6.53], like Theseus in the labyrinth). 
Cassandra's (and hence the messenger's) words are not free from $\alpha i v i \gamma \mu \alpha \tau \alpha$, not pre-

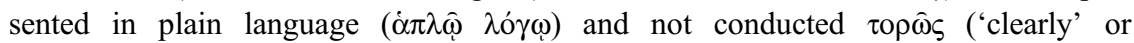
'smartly'). ${ }^{13}$ What has gone unnoticed, however, is the particular resonance of this final adverb. Besides suggesting riddle-free clarity, it evokes a literary trait desired by Callimachus elsewhere. In an epigrammatic fragment, the Alexandrian famously dis-

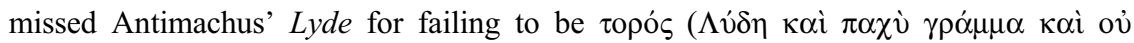

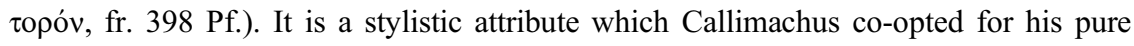
and refined aesthetic, opposed to literary $\pi \alpha \chi v^{\tau} \tau \varsigma .{ }^{14}$ The opening allusion to Prometheus Bound thus opposes Lycophron's cryptic text not only to the plain-speaking Prometheus but also to the Alexandrian's pure aesthetic: unlike either Prometheus or

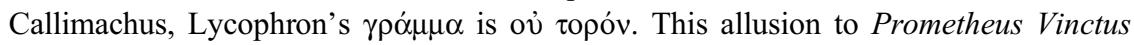
programmatically sets the poem against Callimachus' literary preferences from the very start.

The most significant point of reversal between the two prologues, however, is on the topic of divine inspiration and the sound it produces. Cassandra, just like Callimachus, is inspired directly by Apollo. Lycophron makes this clear at the outset (Cassandra is said to have 'uttered the voice of Phoebus from her bay-chewing throat', 6) just as he does at the poem's close: Cassandra refers to herself as a 'swallow possessed by Apollo'

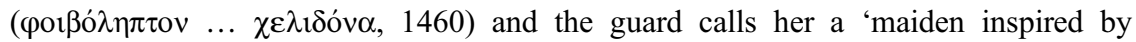
Phoebus' ( $\pi \alpha \rho \theta \dot{v}$ ov $\varphi$ oi $\left.\beta \alpha \sigma \tau \tau^{\prime} \alpha \varsigma, 1468\right) .{ }^{15}$ This Apolline inspiration, however, results in a different form of song from that favoured by the Callimachean Apollo. The Alexandrian god favoured a slender Muse (Mov̂ $\sigma \alpha \nu . . \lambda \varepsilon \pi \tau \alpha \lambda \varepsilon \dot{\eta} \nu$, fr. 1.24), while Callimachus distanced himself from 'song that makes much noise' ( $\mu \varepsilon \dot{\gamma} \alpha \psi$ $\psi \varphi \dot{\varepsilon} 0 v \sigma \alpha \nu$

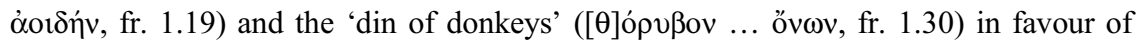

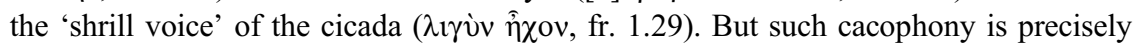
the kind of sound that emerges from Cassandra's mouth: framing the statement of her Apolline inspiration (6), we hear that she utters an 'immense all-mixed shout'

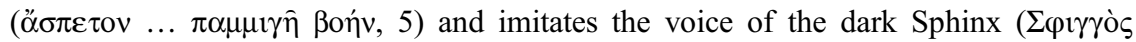

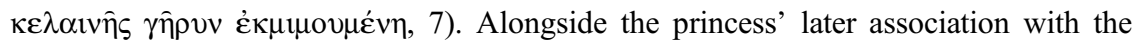
Sphinx, Maenads, Sirens, Sibyl and Bacchants (1461-6), this suggests a different kind of acoustic from that favoured by Callimachus' Apollo. ${ }^{16}$

This alternative aesthetic is reinforced by a string of allusions to earlier passages of din and disarray in the Greek literary tradition. Scholars have previously focussed on the significance of $\pi \alpha \mu \mu \mathrm{\gamma} \hat{\eta}$ in this regard: the rare word is previously used only of non-Greeks, especially Persians; it thus marks Cassandra's speech as exotic and foreign, precisely how Callimachus brands his literary detractors. ${ }^{17}$ To this point,

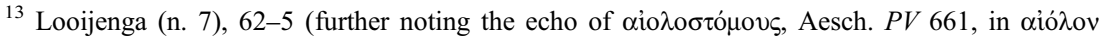
$\sigma \tau o ́ \mu \alpha, 4) ;$ Sens (n. 9), 300-1; McNelis and Sens, 54-5. The Aeschylean authenticity of $P V$ was not doubted in antiquity: M. Griffith, The Authenticity of Prometheus Bound (Cambridge, 1977), 226-45; id., Aeschylus Prometheus Bound (Cambridge, 1983), 32.

${ }^{14}$ For the stylistic associations of $\tau$ opó $\varsigma$, see N. Krevans, 'Fighting against Antimachus: the Lyde and the Aetia reconsidered', in M.A. Harder et al. (edd.), Callimachus (Groningen, 1993), 149-60, at 158.

${ }^{15}$ The poem's framing references to Cassandra's 'crooked speech' $(\lambda \mathrm{o} \xi \hat{\omega} v \ldots$. $\varepsilon \dot{\epsilon} \hat{\omega} v, 14 ; \lambda \mathrm{o} \xi$ òv ... $\mu \hat{v} \theta o v, 1467-8)$ also evoke the cult title of Apollo Loxias: Looijenga (n. 7), 69; cf. schol. Alex. 1467a, page 260.12-13 Leone; Tzetz. Alex. 1466, page 397.12-16 Scheer.

${ }_{16}$ For the parallel between Cassandra and the Sirens (both failed singers), see E. Pillinger, Cassandra and the Poetics of Prophecy in Greek and Latin Literature (Cambridge, 2019), 133-8.

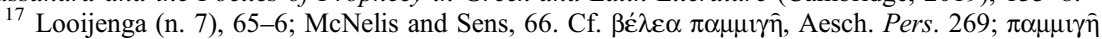

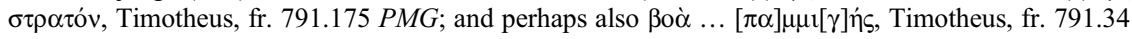


however, we may also add the noun $\gamma \hat{\eta} \rho v v$ in verse 7, a Homeric hapax legomenon which in the Iliad relates to the din of the Trojan troops, precisely because they do not share one language- their voices are all mixed together (Il. 4.436-8):

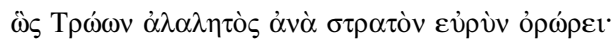

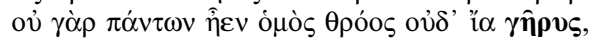

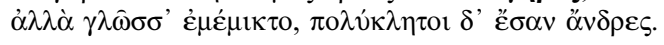

So arose the hubbub of the Trojans through the wide army; for there was no common speech nor single language shared by all of them, but their tongues were mixed and they were men summoned from many different lands.

Through this reuse of a Homeric rarity, Cassandra is aligned with foreign, alien sounds, which are distinctively noisy and cacophonous ( $\dot{\alpha} \lambda \alpha \lambda \eta \tau$ tó $\varsigma, \theta \rho o ́ o \varsigma)$-appropriately so for

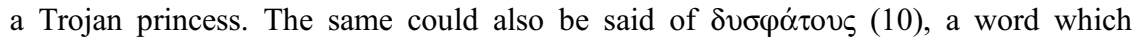
appears only once previously in the literary tradition, again of Cassandra's prophecies,

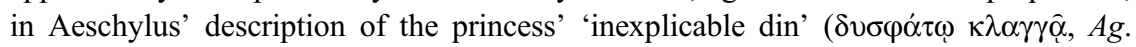
1152). ${ }^{18}$ Through this dense network of sonic allusions, Lycophron establishes a sense of jumbled disorder and acoustic chaos. The Alexandra sets itself up as sonically antithetical to Callimachus' preferences in the Aetia prologue. ${ }^{19}$

Such an acoustic aesthetic is reinforced at the end of the poem when Cassandra asks herself why she is 'barking at length' to the deaf elements of nature ( $\mu \alpha \kappa \rho \grave{\alpha} . . \beta \alpha v$ $\zeta \omega$,

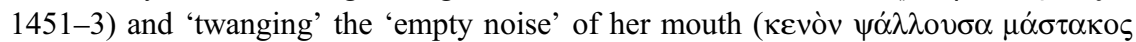

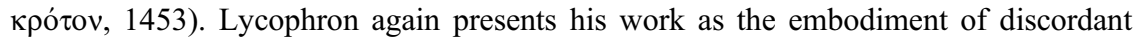
non-Greek sound: the verb $\beta \alpha v ́ \zeta \omega$ dehumanizes Cassandra, associating her with the barking of beasts, ${ }^{20}$ while her lengthy speech aligns her with the kind of poetry that Callimachus rejects in the Aetia prologue ( $\mu \alpha \kappa \rho \alpha \dot{\alpha}, 1451 \sim \mu \alpha \kappa \rho \eta \dot{v}$, fr. 1.10). Particularly revealing, however, is the rare verb $\psi \alpha \dot{\alpha} \lambda \lambda \sigma v \sigma \alpha$, usually used of plucking a bow- or lyre-string and thus ripe for metapoetic interpretation: as elsewhere in the poem, Cassandra's identity blurs with that of the guard and poet, presenting the

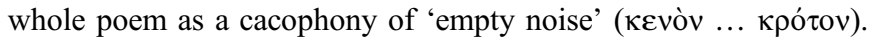

In addition, Cassandra's closing words here evoke the Aesopic fable of the hedonistic cicada and the hard-working ant, a tale which similarly stresses the futile din of song. While the ant secured hibernal provisions by working throughout the summer, the cicada spent all its time singing, was destitute when winter arrived, and received no sympathy or support from the industrious ant. The moral, it seems, is that there is

PMG (suppl. Diehl). Contrast Callimachus' association of his enemies with the Massagetae, the Persians and the Medes (fr. 1.15-16, 18).

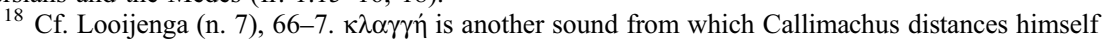
in the Aetia prologue: his mention of the cranes and the Pygmies (fr. 1.13-14) famously evokes $I l$. 3.2-6, with its triple repetition of the noun (again in a description of the noisy Trojans): cf. B. Acosta-Hughes and S.A. Stephens, 'Rereading Callimachus' Aetia fragment 1', CPh 97 (2002), 238-55, at 247-8.

19 Pindar's second dithyramb (fr. 70b S.-M.) offers a further allusive prism through which to read both texts, given its own programmatic 'poetics of sound' (J.I. Porter, The Origins of Aesthetic Thought in Ancient Greece: Matter, Sensation, and Experience [Cambridge, 2010], 378-83). For Callimachus, cf. D.T. Steiner, 'The poetics of sound: Callimachus' rereading of Pindar fragment 70b S.-M.', CPh 110 (2015), 99-123; for Lycophron, Durbec (n. 2), 30.

${ }^{20} \mathrm{Cf}$. an epigram by Leonidas of Tarentum, where the same verb is used of the once noisy iambographer Hipponax $\left(\beta \alpha u ̛ \xi \alpha \varsigma, 58.3\right.$ Gow-Page = Anth. Pal. 7.408.3), who is now quiet in death (öp $\tau_{1} . .$.

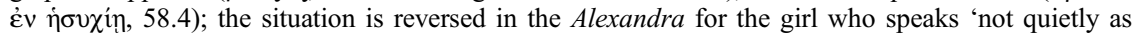

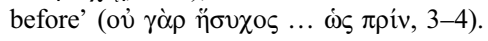


an appropriate time for both work and play; industry is ultimately rewarded. This fable reaches us from antiquity in numerous forms, suggesting its enduring popularity. ${ }^{21}$ But in one particular version, recounted by the rhetor anonymus Brancatianus, we read that

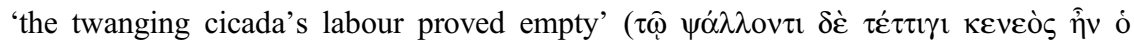
$\pi$ óvos) and that the ant, rather than offering any help, told its suffering peer to keep

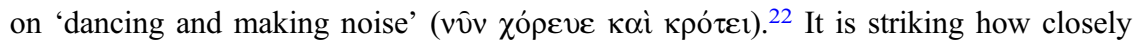
Lycophron's Cassandra echoes the verbal core of this fable: she 'twangs empty

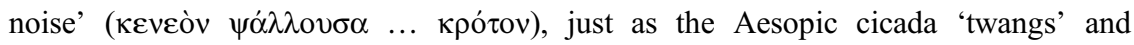

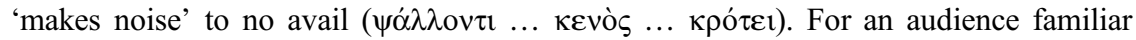
with this fable, Cassandra aligns herself with the cicada. ${ }^{23}$ The insect proves an apt parallel for both the nature and the consequences of her song: both singers produce an unwelcome, cacophonous din (expressed through the onomatopoeic sibilance of

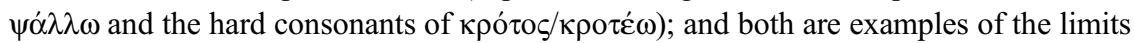
and failings of singing: the cicada's music fails to secure any sustenance, while Cassandra's prophecy fails to persuade its audience (Alex. 1454-7). By alluding to this fable, Lycophron reinforces the distinctive aesthetic of his poem: it is not only a discordant racket but also an account of a prophecy that is destined to fall on deaf ears.

Here too, however, Lycophron appears to be positioning himself squarely against Callimachus. Given the contents of this fable, the allusion invites a polemical revaluation of the cicada from the Aetia prologue. The animal stood there as a symbol of pure, refined sound in comparison to the braying of donkeys (fr. 1.29-32), but Lycophron introduces another tradition in which the insect was a noisy nuisance: the

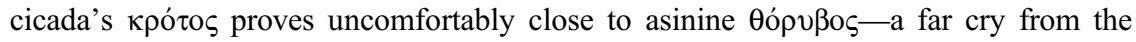

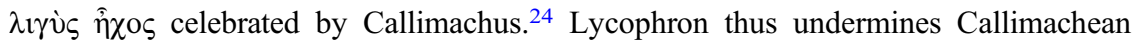
tradition by re-appropriating its strategies: as scholars have long recognized, the fable tradition is a significant element underlying Callimachus' programmatics, especially his contrast between the donkey and the cicada (cf. 184 Perry). ${ }^{25}$ But whereas Callimachus aligned himself with the cicada as an emblem of delicate song, Lycophron's Cassandra adopts the same bestial mascot for different ends: it has become a symbol of disruptive discord. ${ }^{26}$ By echoing and inverting Callimachus' programmatic

${ }^{21}$ See F.R. Adrados, History of the Graeco-Latin Fable (Leiden, 1999-2003), 3.146-9, 3.649-50. Cf. Babrius 140 (373 Perry); Fab. Aphth. 1 Hausrath-Hunger (cf. G54 van Dijk); Fab. 114, Ib and III Hausrath-Hunger.

${ }^{22}$ Fabulae rhetoris anonymi Brancatiani 1 Hausrath-Hunger; originally published by F. Sbordone, 'Recensioni retoriche delle favole esopiane', RIGI 16, fasc. 3-4 (1932), 35-68, at 38.

${ }^{23}$ The Codex Brancatianus is a Byzantine collection, but-as with other fables-it is likely that older versions of this story circulated far earlier, especially given the numerous versions that survive today (see n. 21 above). For the history of Greek fable from Archaic to Hellenistic times, see Adrados (n. 21), 1.139-714.

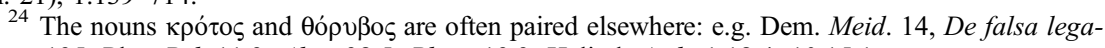
tione 195; Plut. Pel. 11.3, Alex. 38.5, Phoc. 19.3; Heliod. Aeth. 1.18.4, 10.15.1.

${ }^{25}$ Callimachus and fable: B. Acosta-Hughes and R.S. Scodel, 'Aesop poeta: Aesop and the fable in Callimachus' Iambi', in M.A. Harder et al. (edd.), Callimachus II (Leuven, 2004), 1-21. Donkey and cicada: A. Ambühl, 'Callimachus and the Arcadian asses: the Aitia prologue and a lemma in the London scholion', ZPE 105 (1995), 209-13, at 211.

26 The description of Dawn leaving her husband (Ti $\theta \omega v o ̀ v ~ . . . \mid \lambda ı \pi 0 \hat{} \sigma \alpha, 18-19)$ may also allude to the Callimachean cicada, recalling Tithonus' famous metamorphosis into that insect after being abandoned by Dawn in his old age. Yet here too Lycophron perverts the motif: this future cicada is denied 'wings' (contrast $\pi \tau \varepsilon \rho$ ócıs, Aet. fr. 1.32), which instead belong to the 'winged runner' of the guard's simile ( $\pi \tau \eta v o ́ \varsigma, 15)$ and Dawn's 'winged' steed, Pegasus $(\pi \tau \varepsilon \rho o i \varsigma, 17)$. Lycophron robs Callimachus' metapoetic emblem of one of its key attributes, winged lightness. 
proclamations, Lycophron thus carves out his own distinctive and alternative aesthetic, centred on raucous noise: an apt metaphor for the linguistically obscure Alexandra. At both the outset and the close of his poem, Lycophron positions himself agonistically against Callimachus' programmatic preferences.

Lycophron's aesthetic relationship with Callimachus is not restricted to the Aetia prologue, however. The guard's programmatic language can also be interpreted on a wider level as a response to Callimachus' more general criticisms of tragedy. At various points in his work (especially the Iambi and the epigrams), Callimachus appears to disparage tragedy as an art form. ${ }^{27}$ In one epigram, he pictures a Dionysian mask yawning at the tedious repetition of popular tragic lines (Epigr. 48 Pf. $=26$ Gow-Page $=$ Anth. Pal. 6.310-verse 6 quotes Eur. Bacch. 494). In an unplaced fragment of the Iambi, an unknown speaker claims that 'the tragic actor did not rouse us yesterday' - an unfavourable assessment of the genre's emotional potential (oủ $\pi \rho \hat{\omega} v \mu \grave{\varepsilon} v \dot{\eta} \mu \hat{i} v$ ò $\tau \rho \alpha \gamma \omega \delta$ ò $\varsigma$ ทे of tragic failure (Epigr. 59 Pf./Gow-Page=Anth. Pal. 11.362); as Gow and Page conclude, 'the way to lose your friends is to write drama' ${ }^{28}$ It is difficult to draw a coherent aesthetic from such contextless snippets, but even so the cumulative impression is that Callimachus scorned tragedy as a literary form. And from other poems it seems that this dislike was particularly rooted in the raucous noise and popular appeal of tragedy: in another unplaced fragment of the Iambi, we find a reference to 'some bellowing, tragic

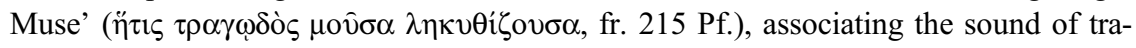
gedy with somebody speaking into a lekythos. ${ }^{29}$ Most revealing, however, is Callimachus' assertion in Iambus 2 that tragedians 'have the voice of those who inhabit

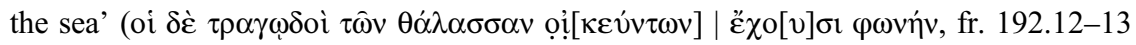
Pf.). The meaning of this phrase has been disputed: some take it to refer to the muteness of fish, but a range of parallels and the larger context clearly favour a reference to their allegedly harsh and unmusical sound. ${ }^{30}$ For Callimachus, tragedians match non-human fish in their inarticulate and grating noises, a foil to his own refined poetics. Lycophron, by contrast, champions the din of tragedy and embraces it as his modus operandi.

As a final element in this aesthetic dichotomy, we should also cite Callimachus' epigram on Theaetetus (Epigr. 7 Pf. $=57$ Gow-Page =Anth. Pal. 9.565):

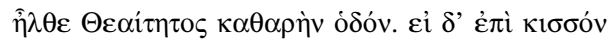

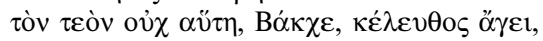

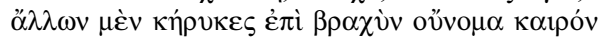

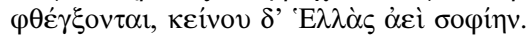

${ }^{27}$ See R.F. Thomas, 'New Comedy, Callimachus, and Roman poetry', HSPh 83 (1979), 179-206, at 181-90; M. Fantuzzi, 'Epigram and the theater', in P. Bing and J.S. Bruss (edd.), Brill's Companion to Hellenistic Epigram (Leiden, 2007), 477-95, especially 477-87; A. Dale, 'Dithyramb, tragedy, and Callimachus: the New Music and its reception', in D. Castaldo et al. (edd.), Poesia, musica e agoni nella Grecia antica (Galatina, 2010-11), 1.369-83, at 378-82.

28 A.S.F. Gow and D.L. Page, The Greek Anthology: Hellenistic Epigrams (Cambridge, 1965), 2.211 .

29 The image recalls Aristophanes' famous phrase $\lambda \eta \kappa v ́ \theta$ เov $\alpha \dot{\alpha} \hat{\prime} \lambda \varepsilon \sigma \varepsilon v$ (Ran. 1200-48; cf. Hor. Epist. 1.3.14). See too Thomas (n. 27), 189-90 for the verb's further possible association with triviality.

${ }^{30}$ See P. Bing, 'The voice of those who live in the sea: Empedocles and Callimachus', ZPE 41 (1981), 33-6; Dale (n. 27), 380. Contrast A. Kerkhecker, Callimachus' Book of Iambi (Oxford, 1999), 54-8. For noisy fish, cf. Sen. Apocol. 5; Ael. NA 10.11. 
Theaetetus travelled a pure path. If this road does not lead to your ivy wreath, Bacchus, heralds will proclaim the names of others for a short while, but Hellas will proclaim his wisdom forever.

In this epigram Callimachus acknowledges the popular appeal of Dionysiac art (here not only tragedy but also dithyramb), marked by the ivy-clad road of its divine patron

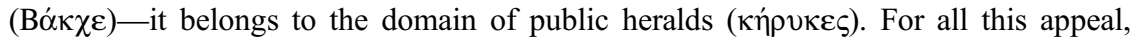
however, the renown it bestows remains short-lived. Theaetetus, by contrast, will endure in memory by following a different 'pure path', not frequently trodden by the masses. The programmatic nature of this epigram is reinforced by its clear links with the Aetia

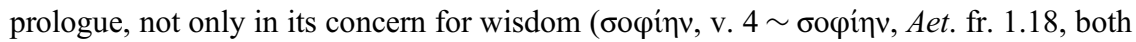
in the same sedes) but also in its assertion of the right kind of road to travel: the pure

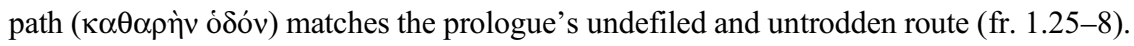
The dismissal of Dionysus, moreover, parallels the prologue's dismissal of the din of donkeys (fr. 1.30-2), an animal which was intimately connected with the god. ${ }^{31}$ This epigram thus complements the programmatic polemic of the Aetia prologue, directing it specifically against the popular art of Dionysus. Indeed, reading both Callimachean texts together, we can gain a clear sense of an opposition between Callimachus' pure and exclusive Apollo and the common and defiled Dionysus.

Here too we can see Lycophron's prologue positioning itself against such polemic. The Callimachean reference to кир икє Alexandra, spoken by an unnamed herald, while the Alexandra's tangled hodological imagery contrasts strongly with the Callimachean 'pure path'. ${ }^{32}$ Most significantly, however, Lycophron does not distance himself from Dionysus, as Callimachus had: instead, Cassandra speaks from a programmatically 'Bacchic mouth' ( $\dot{\eta} \delta$ ' ěv $\theta \varepsilon o v$

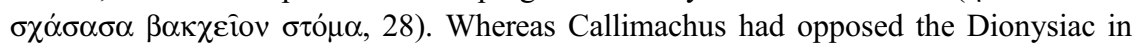
his epigram and favoured the Apolline in the Aetia prologue, Lycophron collapses the opposition between these two gods, embracing the influence of both: the prologue begins with Apollo (6) and closes with Dionysus (28). ${ }^{33}$ The Alexandra, therefore, selfconsciously unravels Callimachus' polarized poetics: it embodies both Bacchus and Apollo, both Dionysiac noise and Apolline inspiration. ${ }^{34}$ Through repeated engagement with Callimachean purple patches, Lycophron thus articulates a different aesthetic from that of his Alexandrian predecessor: one that embraces the boisterous noise of tragedy and aims for literary grandeur. Indeed, we may even see his rebellion against the Callimachean tradition mirrored and thematized by Cassandra's own rejection of Callimachus' patron god, Apollo (cf. Alex. 1457).

31 Cf. Ambühl (n. 25), 211-12.

32 The epigram's ódóv provides a parallel to Lycophron's $\delta 1 \varepsilon \xi o ́ \delta o v \varsigma(14)$ - the only road image in the Alexandra prologue which does not find a lexical equivalent in the Aetia prologue. Moreover, the

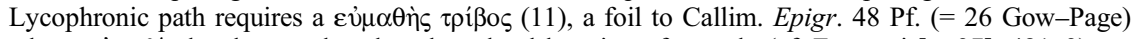
where $\varepsilon \dot{j} \mu \alpha \theta^{\prime}$ in has been reduced to the school learning of tragedy (cf. Fantuzzi [n. 27], 481-2).

${ }^{33}$ Cf. C. Kossaifi, 'Poétique messager. Quelques remarques sur l'incipit et l'épilogue de l'Alexandra de Lycophron', in Cusset and Prioux, 141-59, at 145, further noting Alex. 1464,

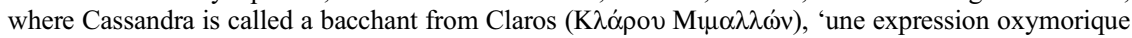
qui l'associe à la fois à Apollon, dieu de Claros en Ionie, et à Dionysos, maître des ménades'; cf. Looijenga (n. 7), 68.

34 Similarly, McNelis and Sens, 64-6 note how the Alexandra collapses the Aetia prologue's distinction between Aeschylean and Euripidean styles of poetry; Callimachus' prologue, though, already deconstructs this opposition: T.J. Nelson, 'The shadow of Aristophanes: Hellenistic poetry's reception of comic poetics', in M.A. Harder et al. (edd.), Drama and Performance in Hellenistic Poetry (Leuven, 2018), 225-71, at 250. 


\section{A PRESCRIPTED AESTHETIC: 'LYCOPHRON' AND RHETORICAL FRIGIDITY}

However, the Alexandra should not-and cannot—be viewed purely through a Callimachean lens. Such a framework is overly restrictive and prevents us from seeing many other aspects of Lycophron's work. As we have noted above, the poem can beand has indeed been-subjected to other aesthetic interpretations through completely different frames of reference, such as Sistakou's analogy of Late European Romanticism. In the second half of this article, we wish to take the poem in yet another direction, by exploring how it constructs an alternative literary historical framework beyond Callimachus, drawing especially on the earlier literary criticism of Aristotle. The key to this interpretation lies in the name of the poem's author, 'Lycophron'.

As is well known, names and naming play a major part in the obscure and riddling style of the Alexandra. Rarely does Lycophron name a person, place or god directly: instead, he intimates identities through a range of epithets, metaphors, analogies, periphrases, kennings, synecdoches, metonymies and more. ${ }^{35}$ The poet's interest in onomastics is reflected in the numerous exploring how names are shaped and changed over time. ${ }^{36}$ And even when figures are named directly, questions of identity and status remain: the Cyprian heroes Cepheus and Praxandrus, for example, are pointedly called 'a nameless brood, not

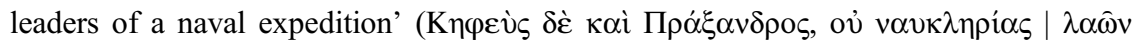

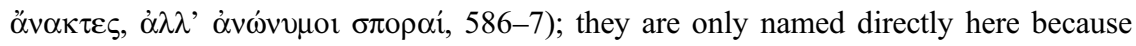
they have never featured in the literary tradition before. ${ }^{37}$ Individual names can also carry much significance within the poem: Lycophron's use of the name 'Alexandra', for example, rather than the more familiar 'Cassandra', invites a false etymology (derived from $\dot{\alpha}-\lambda \dot{\varepsilon} \xi \omega$ ), foregrounding the poem's central themes of miscommunication and mediated language. We never hear Cassandra's voice directly; she is indeed 'without speech'. ${ }^{38}$ Even from this brief survey, it is clear that the Alexandra is deeply engaged in questions of names, their meaning and their interplay with individuals' identity. It is a poem that is self-consciously and deeply attuned to onomastics.

One name that has received far less attention in modern scholarship, however, is that attributed to the poet of the poem: 'Lycophron'. Traditionally, this name has been understood to refer to Lycophron of Chalcis, the Ptolemaic playwright and scholar. However, such an attribution was already doubted in the scholia to the Alexandra

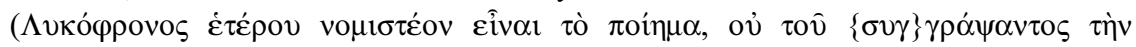
$\tau \rho \alpha \gamma \omega \delta i$ í $\alpha$, schol. Alex. 1226, page 226.5-6 Leone) and with good reason: most ancient sources merely ascribe the poem to an unspecified 'Lycophron', and it is only a handful

35 See e.g. M.G. Ciani, “Scritto con mistero”: osservazioni sull'oscurità di Licofrone', GIF 25 (1973), 132-48; G. Lambin, L'Alexandra de Lycophron (Rennes, 2005), 233-83; C. Cusset, 'Les détournements du nom propre: l'exemple de Lycophron', in Lalies: Actes des sessions de linguistique et de literature (Paris, 2007), 199-212; E. Sistakou, 'Breaking the name codes in Lycophron's Alexandra', in Cusset and Prioux, 237-58.

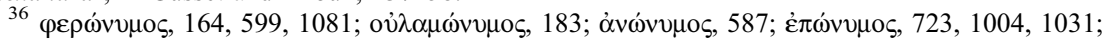

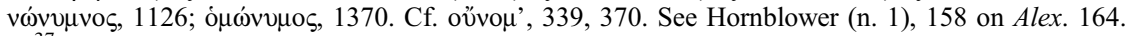

${ }^{37}$ Lycophron acknowledges the pair's absence from the Homeric Catalogue of Ships: schol. Alex. 586, pages 116.14-117.5 Leone; Tzetz. Alex. 586, pages 201.9-202.3 Scheer. Other named figures are similarly secondary or otherwise unattested characters: Sistakou (n. 35), 244 n. 19, 249.

${ }^{38}$ Cf. M. Fusillo, A. Hurst and G. Paduano, Licofrone: Alessandra (Milan, 1991), 31; C. Cusset, 'Dit et non-dit dans 1'Alexandra de Lycophron', in M.A. Harder et al. (edd.), Hellenistic Poetry Beyond the Canon (Leuven, 2006), 43-60, 45 with n. 13. Note too the juxtaposition 'A $\lambda \varepsilon \xi \alpha \dot{\alpha} v \delta \rho \alpha$ $\lambda$ ó $\gamma \omega v$ at the end of the prologue (Alex. 30): McNelis and Sens, 51. 
of late testimonia (Tzetzes and the Suda) that directly identify this figure with the Ptolemaic poet. ${ }^{39}$ In any case, the ascription to the Chalcidian is impossible to maintain if the poem dates from the start of the second century B.C.E., as we believe. ${ }^{40}$ It should thus be viewed with considerable scepticism. Most previous scholars who have accepted the later dating of the poem conclude that we can know nothing more about its actual author, and that the Alexandra, like many other works in antiquity, is simply pseudonymous: it may or may not have been composed by some unknown 'Lycophron' ${ }^{41}$ In this contribution, however, we would like to propose an alternative solution to this problem of authorial identity, one which simultaneously enriches our appreciation of the poem's aesthetic positioning.

We propose that the transmitted ascription to 'Lycophron' is in fact a pen name adopted by the poem's original author to embody and advertise his stylistic affiliation. It does not primarily associate the Alexandra with the famous Alexandrian playwright, an association which presumably only developed later (as the general lack of specificity in our earlier testimonia may suggest): given the Chalcidian's reputation for tragedy, scholarship and wordplay, he was a plausible candidate for anybody who wanted to attach a concrete personality to the poem. ${ }^{42}$ Instead, we propose that the author of the poem pseudonymously adopted the name 'Lycophron' to evoke an earlier literary namesake from the Classical period: Lycophron the sophist ( $83 \mathrm{DK}=38$ Laks-Most). Little is known of this figure today. An allusion in a pseudo-Platonic letter suggests that he may have resided at the court of Dionysius II in Sicily during the early fourth century B.C.E. (Epist. 2.314d1-5), but this reference has often been suspected and we otherwise know nothing about his life. Yet he was evidently an author of considerable repute in antiquity: Aristotle cites him repeatedly in a wide range of works-in a wider range, in fact, than he mentions other 'sophists' more familiar to us, such as Gorgias (Metaph. 1045b; Pol. 1280b; Ph. 185b; Rh. 1405b, 1406a; Soph. el. 174b; Nob. fr. 91 Rose). ${ }^{43}$ Most citations concern Lycophron's views on politics and metaphysics, but several provide significant insight into his more literary pursuits. In Sophistici

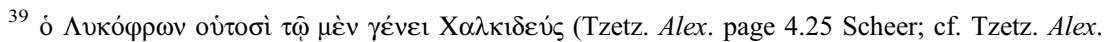

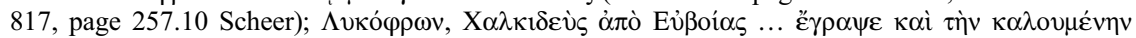

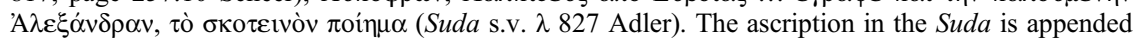
to the end of Lycophron's entry after a list of his tragedies-almost as an afterthought. Other testimonia are prosopographically imprecise: e.g. latebrasque Lycophronis atri (Stat. Silv. 5.3.157); $\dot{\eta}$

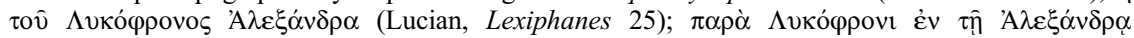
(Artem. 4.63). For a survey of testimonia, see A. Berra, 'Obscuritas lycophronea: les témoignages anciens sur Lycophron', in Cusset and Prioux, 259-318, at 271-314.

${ }^{40}$ For other proposed identifications, see e.g. Lambin (n. 35), 20-4, who posits a different thirdcentury Lycophron, the son of Lycus of Rhegium; and K. Ziegler, 'Lykophron der Tragiker und die Alexandrafrage', $R E 13$ (1927), 2316-81, at 2381, who supposes that the poet may be the homonymous grandson of the Ptolemaic tragedian.

${ }^{41}$ e.g. Hornblower (n. 1), 39-41; McNelis and Sens, 11. P.M. Fraser, 'Lycophron (2)', in $O C D^{3}$ (Oxford, 2003), 895-6, at 896 considers the name a 'deliberate pseudepigraphon' which offers an 'ironic reminiscence' of Lycophron of Chalcis, but he does not explain this irony.

${ }^{42}$ The Chalcidian was a member of the Ptolemaic Pleiad of tragedians (100 $\operatorname{Tr} G F$; A. Kotlińska-Toma, Hellenistic Tragedy [London, 2015], 74-90), wrote a treatise on comedy in at least nine books $(\pi \varepsilon \rho i \kappa \omega \mu \omega \delta i \alpha \zeta$; cf. Ath. Deipn. 11.485d) and was famous for his anagrams (iov

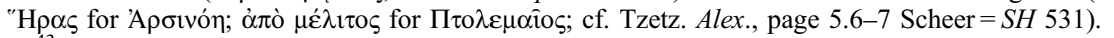

43 S. Giombini, 'Lycophron: a minor sophist or a minor Socratic?', Philosophical Inquiry 40 (2016), 74-94 offers a recent survey of the sophistic Lycophron, noting the frequency of Aristotle's citations at pages 79-80; cf. too J. Vahlen, 'Der Sophist Lykophron', RhM 21 (1866), 143-6; H. Hofmann, 'Lykophron der Sophist', RE Suppl. 14 (1974), 265-72; A. Laks and G.W. Most, Early Greek Philosophy (Cambridge, MA, 2016), 9.120-31. 
elenchi (174b), we hear that the sophist was a refined rhetorician, skilfully able to rebrand a topic about which he had little material, as when he was asked to praise a lyre. According to the gloss of Alexander of Aphrodisias, he praised the lyre for only a short while, before turning to the eponymous constellation, 'Lyra', a topic on which he was far better equipped. ${ }^{44}$ Judging by this anecdote, he was evidently well attuned to the polysemous potential of language.

Most significantly for us, however, he is also cited in Aristotle's Rhetoric as a prime example of rhetorical frigidity, the locus classicus for ancient discussions of stylistic

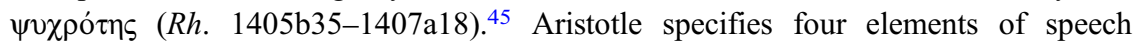
which contribute to such frigidity: the use of compound words (

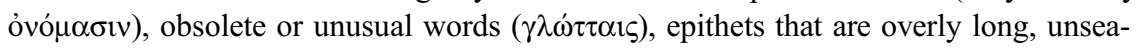
sonable or too crowded ( and metaphors ( $\mu \varepsilon \tau \alpha \varphi \rho \rho \alpha i \varsigma)$. To exemplify these stylistic flaws, he draws illustrations from three sophists: Gorgias, Alcidamas and-crucially-Lycophron, whose work provides examples of the first two categories (Rh. 1405b35-1406a10):

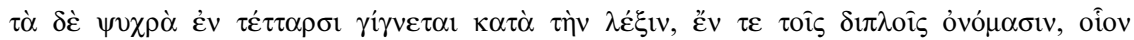

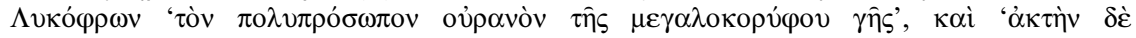

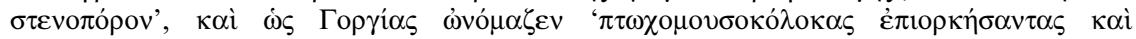

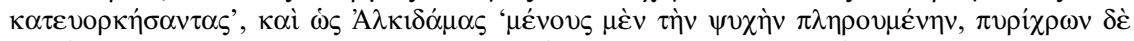

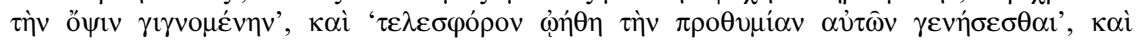

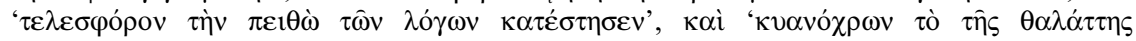

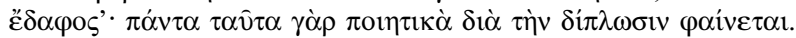

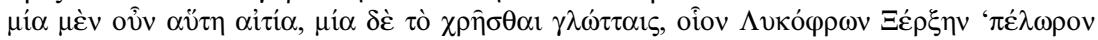

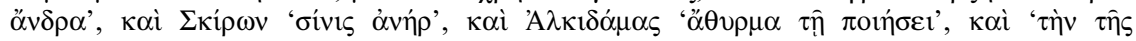

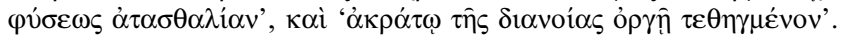

Frigidity of style comes about in four ways: first, through compound words, such as Lycophron's 'the many-faced heaven of the mighty-peaked earth' and 'the narrow-straited shore'; Gorgias too used to speak of 'beggar-Muse-flatterers, false-oath-swearers and good-oath-swearers'; and Alcidamas has 'his soul filling with anger, his face turning fire-hued', and 'he thought their zeal would be fulfilment-bringing', and 'he made the persuasion of his words fulfilment-bringing', and 'the azure-hued floor of the sea'. These all seem poetic because of their compound form.

So this is one cause of frigidity. Another is the use of rare words, such as Lycophron's description of Xerxes as 'a gargantuan man' and of Sciron as 'a scourge of a man'; Alcidamas too has 'bibelots for poetry', 'the effrontery of nature', and 'whetted by his mind's unadulterated ire'.

In Aristotle's opinion, the sophistic Lycophron stood alongside Gorgias and Alcidamas as an archetype of rhetorical frigidity. He was known for his elaborate compound words, such

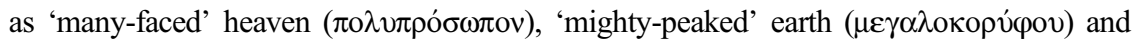
the 'narrow-straited' shore ( $\sigma \tau \varepsilon v o \pi$ ó $о \nu)$; and also for his use of unusual and recherché lexical items, describing Xerxes as 'a gargantuan man' ( $\pi \dot{\varepsilon} \lambda \omega \rho \circ \nu$ ö $v \delta \rho \alpha)$ and Sciron as

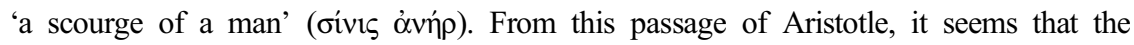
name 'Lycophron' was already larded with a host of aesthetic associations by the fourth century: the name was ripe to become a buzzword for the 'frigid' style.

44 Alex. Aphr. on Arist. Soph. el. 15.174b30, CAG II.3, 118.31-119.3. However, this gloss may simply be Alexander's own hypothesis: Laks and Most (n. 43), 9.120, 9.129 n. 1.

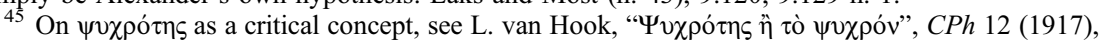

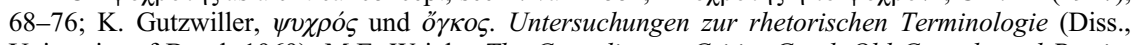
University of Basel, 1969); M.E. Wright, The Comedian as Critic: Greek Old Comedy and Poetics (London, 2012), 108-10. 
From this literary background, the ascription of the Alexandra to a 'Lycophron' gains considerable point: Aristotle's four stylistic traits of rhetorical 'frigidity' map perfectly onto core aspects of the poem's design. ${ }^{46}$ It too is characterized by elaborate compound words, many of which are hapax or proton legomena, such as $\lambda \nu \kappa \alpha$ vo $\mu$ ó $\rho \omega v$ ("wolf-

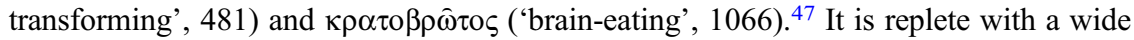
range of $\gamma \lambda \hat{\omega} \tau \tau \alpha \iota$, including foreign borrowings (for example the Egyptian $\beta \hat{\alpha} \rho ı v, 747$ ) and rarities of the literary tradition (for example $\tau \imath \theta \alpha \_\beta \omega \sigma \sigma o v \tau o \varsigma, 622$; cf. Od. 13.106). ${ }^{48}$ It contains numerous strings of lengthy and elaborate epithets, especially

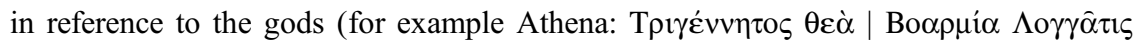

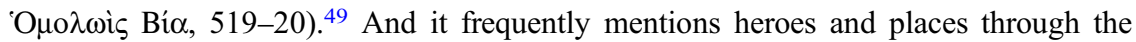
obscuring veil of metaphor (such as the sequence of birds and fish used to characterize Cassandra's assailant, Locrian Ajax). ${ }^{50}$ In the past, scholars have considered many possible precedents for these stylistic elements, including Aeschylean tragedy, dithyrambic New Music and oracular literature. ${ }^{51}$ But alongside these various influences we should now set the 'frigid' style of classical rhetoric. ${ }^{52}$ The Alexandra epitomizes all four of Aristotle's defining criteria for this aesthetic, pushing them to their extremes. Aristotle comments that these stylistic features verge on the poetic when used in excess

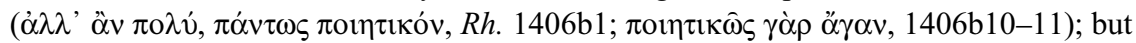
by taking them to an even greater extreme, the Alexandra has become hyper-frigid and hyper-poetic, near impenetrable in its language. What for Aristotle was a stylistic flaw ('frigidity') has here become the poem's key compositional strategy. In its ascription to 'Lycophron', we suggest that the poem self-consciously acknowledges this rhetorical precedent, situating itself within the same 'frigid' tradition as the classical sophist. In looking back to Aristotle's criticisms, the poem embodies and positively reappraises rhetorical frigidity: the ascription serves as a pen name, marking the poem's aesthetic affiliation.

${ }^{46}$ Cf. already Lambin (n. 35), 261-3, who cites this passage as a 'guide' to explore the Alexandra's stylistic features but fails to dwell on its larger significance or the prominence of the sophistic Lycophron.

${ }^{47}$ On Lycophron's lexical creativity, see N. Guilleux, 'La fabrique des hapax et des prôton legomena dans l'Alexandra, entre connivence et cryptage', in Cusset and Prioux, 221-36. Among the poem's 3,000 or so words, 518 are hapax legomena and 117 proton legomena: Ziegler (n. 40), 2343-8. Such lexical creativity resonates with the Gorgianic sophists' interest in the power of language.

${ }^{48}$ Foreign words: Hornblower (n. 1), 53. Homeric rarities: A. Rengakos, 'Lykophron als Homererklärer', ZPE 102 (1994), 111-30.

${ }^{49}$ For the historical and literary significance of such epithets, see Hornblower (n. 1), 62-93; McNelis and Sens, 38-46.

${ }^{50}$ Ajax is pictured as a vulture (

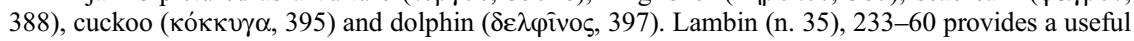
catalogue of metaphors in the Alexandra, with further discussion.

51 Aeschylus: S.R. West, 'Notes on the text of Lycophron', CQ 33 (1983), 114-35, at 114. New Music: McNelis and Sens, 15-22, 59. Oracles: S.R. West, 'Lycophron's Alexandra: "Hindsight as foresight makes no sense?", in M. Depew and D. Obbink (edd.), Matrices of Genre: Authors, Canons, and Society (Cambridge, MA, 2000), 153-66. Cf. Arist. Poet. 1458a21-31 on the overuse

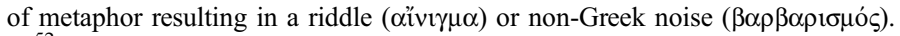

52 These categories of influence are not completely separate: Aristotle himself associated noisy ( $\psi \circ \varphi \omega ́ \delta \varepsilon 1 \varsigma)$ dithyrambists with the 'frigid' style through their use of compound words (Rh. 1406b1-2; cf. Demetr. Eloc. 116). In the following paragraphs, however, we consider the Alexandra's broader associations with stylistic frigidity and the sophistic Lycophron in particular. 
Such an argument is bolstered by the widespread use of pen names and artistic aliases in antiquity. ${ }^{53}$ Already in the Archaic era, we could cite the precedent of the Homeric Hymn to Apollo, a poem which famously fashions itself as a 'Homeric' composition through allusion to the Homeric biographical tradition (especially Hymn. Hom. Ap. 3.166-76). ${ }^{54}$ But a closer parallel in time is provided by the Tabulae Iliacae, some of which are inscribed with epigrams that assign the work to 'Theodorean techne'. In the past, these attributions prompted numerous speculations surrounding the identity of the tablets' artist(s) or inscriptions' author(s), akin to those which have plagued the composer of the Alexandra. ${ }^{55}$ But in recent years Michael Squire has plausibly reinterpreted the evidence, arguing that these attributions serve as a pen name, marking allegiance to the style of the archaic craftsman Theodorus of Samos, who was renowned for his miniature artistic inventions (Plin. HN 34.83; Posidippus 67 A.-B.). ${ }^{56}$ By alluding to this stylistic precedent, the tablets acknowledge their status as refined, small-scale compositions, situating themselves within a pre-existing artistic tradition. In a similar manner, the pen name of the Alexandra positions the poem within a prior literary history of frigid composition: Lycophron's Hellenistic trimeters embody and exaggerate features of a pre-existing and much-maligned literary aesthetic. ${ }^{57} \mathrm{In}$ its bulky, figurative and foreignizing language, the poem simply 'does what it says on the tin'. It fulfils the literary expectations raised by the poem's alleged authorship. ${ }^{58}$

Besides this general stylistic continuity, the two Aristotelian quotations concerning $\gamma \lambda \omega \hat{\omega} \tau \tau \alpha$ exhibit further significant parallels with the work of our Hellenistic Lycophron. First, the description of Sciron involves onomastic wordplay which mirrors that which we later find in the Alexandra. In myth, Sciron was one of the notorious bandits that ranged the Attic countryside, forcing travellers to wash his feet before kicking them into the sea: his designation as a 'scourge of a man' ( $\sigma i v i \varsigma \dot{\alpha} v \eta \dot{\rho} \rho)$ is thus extremely appropriate. ${ }^{59}$ As Aristotle recognized, however, the noun oivis ('scourge'/'ravager', here used in apposition) was an extremely rare poeticism: it is previously attested only in the manuscripts of Aeschylus' Agamemnon ( $\lambda$ ćov $\tau \alpha$ oiviv, Ag. 717-18) ${ }^{60}$ and

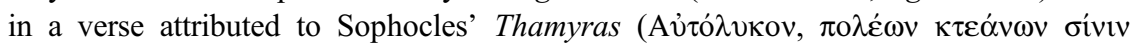

\footnotetext{
53 On allusive names and aliases in the Hellenistic period, see J.H. Klooster, Poetry as Window and Mirror: Positioning the Poet in Hellenistic Poetry (Leiden, 2011), 188-94.

${ }^{54}$ M.L. West, 'The invention of Homer', CQ 49 (1999), 364-82, at 368-72; B. Graziosi, Inventing Homer: The Early Reception of Epic (Cambridge, 2002), 62-6.

${ }_{55}$ See N. Valenzuela Montenegro, Die Tabulae Iliacae: Mythos und Geschichte im Spiegel einer Gruppe frühkaiserzeitlicher Miniaturreliefs (Berlin, 2004), 350-8; M. Squire, The Iliad in a Nutshell: Visualizing Epic on the Tabulae Iliacae (Oxford, 2011), 285.

${ }_{56}$ M. Squire, 'Texts on the tables: the Tabulae Iliacae in their Hellenistic literary context', JHS 130 (2010), 67-96, at 84-90; Squire (n. 55), 283-302.

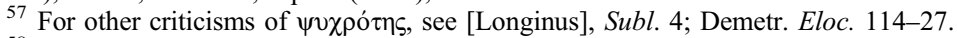

58 A sceptical reader might object that 'Lycophron' is too common a name to bear such a precise and allusive significance (see the various entries in the LGPN [Oxford, 1987-], including e.g. forty Lycophrons from Attica in volume 2). However, the sophist's reputation (through Aristotle) as a literary personality would have strengthened the link, and the erudition required to decode the pen name is no different to that demanded by the rest of the poem.

59 Sciron: Apollod. Epit. 1.2-3; Diod. Sic. 4.59.4; Hyg. Fab. 38; Paus. 1.44.8; Plut. Thes. 10.1. The myth seems to have been popular among Hellenistic poets, e.g. Callim. Hecale frr. 59-60 Hollis; Euphorion, fr. 11.6-9 Lightfoot.

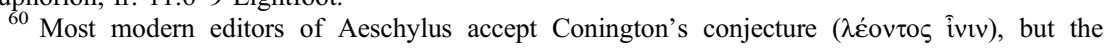
Hellenistic pedigree of the manuscript reading seems to be confirmed by several allusions: $\lambda \dot{\varepsilon}$ ov $\tau \alpha$

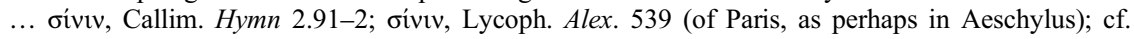
too oivis, Anyte 11.3 Gow-Page=Anth. Pal. 7.202.3. Cf. F. Williams, Callimachus: Hymn to Apollo. A Commentary (Oxford, 1978), 79.
} 
'Арүعї коí $\lambda \omega$, fr. $242.2 \operatorname{Tr} G F) .{ }^{61}$ More commonly, the word served as a proper noun, referring to another mythical Attic bandit, Sinis, who-like Sciron-preyed on unwary wayfarers, catapulting them into the sky from a bent pine tree. ${ }^{62}$ By using the rare word to describe Sciron, the sophistic Lycophron thus collapsed the two mythical figures into a single reference, emphasizing their similarity. After all, both bandits were punished by Theseus with a taste of their own medicine-Sciron hurled into the sea, and Sinis into the air. They are mythical doublets of each other, a point which Lycophron's phrasing implicitly acknowledges. ${ }^{63}$ Such a condensed allusion gives us a taste of the sophist's mythical mastery and allusive sophistication. Crucially for our purposes, however, this onomastic blurring is also a familiar feature of Lycophron's Alexandra, in which characters are often figuratively described through the names of others, as when Agamemnon is presented as Zeus $(1124-5,1369-71)$ and Zeus in turn as Agamemnon (335); they too are doublets of each other, one ruling on earth, the other in heaven. In already transferring names and blurring identities centuries earlier, the sophistic Lycophron provides significant precedent for the indirect and allusive onomastics of the Alexandra.

Most striking of all, however, is the sophistic Lycophron's description of Xerxes as a gigantic figure, a 'gargantuan man' ( $\pi \dot{\varepsilon} \lambda \omega \rho o v$ öv $\delta \rho \alpha$, Arist. Rh. 1406a7-8). The Persian tyrant is described in a similar manner in the Alexandra itself (Alex. 1413-16): ${ }^{64}$

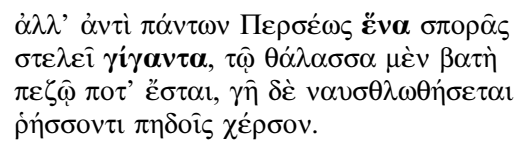

But in return for everything she [sc. Asia] will send forth a single giant from the race of Perseus, who will one day walk over the sea on foot, and sail over the earth, breaking open the dry land with oars.

In the work of both Lycophrons, Xerxes was a gigantic, more-than-human figure. Like

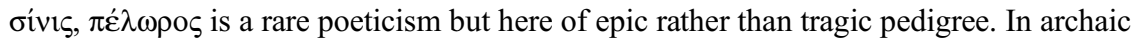
and classical epic, it was regularly used of monsters and giants, to which Xerxes is thus equated. ${ }^{65}$ Admittedly, our absence of the wider context for the sophist's statement makes broader conclusions difficult, and it is possible that both authors were simply drawing independently on a wider analogical tradition of using the Gigantomachy to

\footnotetext{
${ }^{61}$ Given the hexameter form and the possible corruption in the Sophoclean scholia, some scholars have supposed that the verse actually derives from the Epigoni, either the cyclic epic (fr. 8.2 Bernabé) or a poem of that title by Antimachus (J.U. Powell, Collectanea Alexandrina [Oxford, 1925], 247). But this is unlikely: M. Davies, The Theban Epics (Cambridge, MA, 2014), 145.

${ }^{62}$ Sinis: Apollod. Bibl. 3.16.2; Hyg. Fab. 38; Plut. Thes. 8.2. For an alternative version in which Sinis' victims were torn in two between two pine trees, see Diod. Sic. 4.59.2-3; Paus. 2.1.4.

${ }^{63} \mathrm{Cf}$. the frequency with which the pair are juxtaposed elsewhere in literature, e.g. Bacchyl. 18.202, 24-5; Eur. Hipp. 977-80; Ov. Met. 7.440-7.

${ }^{64}$ On the Alexandra's frequent recourse to Gigantomachic imagery, see F.-H. Massa-Pairault, 'Lycophron et les Géants', in Cusset and Prioux, 487-505. Xerxes appears to have been a favourite

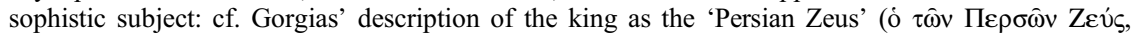
[Longinus], Subl. 3.2=82 B5a DK=32 D30a Laks-Most; cf. Hdt. 7.56).

65 The adjective is used of Gaia (Hes. Theog. 159, 173, etc.), Echidna (Theog. 295, 299), Typhoeus (Theog. 845, 856), Polyphemus (Od. 9.257), Gorgons (Il. 5.741, Od. 11.634, etc.) and dangerous animals, including the Nemean lion (Panyassis, fr. 5 Bernabé) and snakes (Il. 12.220). The only earlier non-epic appearances are Thgn. 9 (again of Gaia) and Pind. fr. 70db.8 S.-M. (extremely fragmentary).
} 
articulate cultural and political oppositions. ${ }^{66}$ But the resemblance is certainly striking and suggests that Aristotle's sophist may have been a model for the poet of the Alexandra in more than just style alone.

We therefore propose that the original poet of the Alexandra adopted 'Lycophron' as a pen name, aligning the poem with a predetermined 'frigid' literary aesthetic. We are not, of course, the first to mention these namesakes in the same breath: already in antiquity, an anonymous commentator on Aristotle attempted to clarify this passage of the Rhetoric by remarking that it refers to 'another Lycophron and not the poet'

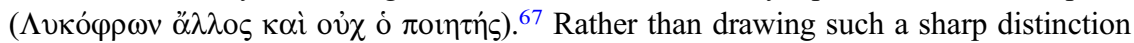
between the two, however, we believe that it is better to see the poet of the Alexandra building on the reputation and the stylistic associations of his predecessor. The poem's ascription advertises its aesthetic credentials. Moreover, if scholars are right to situate the poet of the Alexandra in a South Italian context and to locate the sophistic Lycophron within the Sicilian school of rhetoric headed by Gorgias, we might even see some local pride in this implicit affiliation: both 'Lycophrons' would then be situated within the same geographical environment, and the poet of the Alexandra would be establishing his literary identity through specifically local precedent. ${ }^{68}$ Admittedly, such geographical overlap can be no more than speculation on current evidence, and it is worth acknowledging how little we in fact know of the sophist beyond Aristotle's citations. But in some respects the obscure identity of this earlier author is a perfect complement to the obscure style of the Alexandra itself. The poet's name is the ultimate 'name-code' throughout the whole poem, embodying its stylistic frigidity. However much the Alexandra plays against Callimachus' poetic programme, therefore, it must also be situated within a far broader literary history-and its deep affiliation with rhetorical frigidity demonstrates a further strand of its aesthetic range.

Corpus Christi College, Cambridge

University of Manchester
THOMAS J. NELSON tjn28@cam.ac.uk

KATHERINE MOLESWORTH katherine.molesworth@manchester.ac.uk

${ }^{66}$ Cf. T.J. Nelson, 'Beating the Galatians: ideologies, analogies and allegories in Hellenistic literature and art', in A. Coşkun (ed.), Galatian Victories and Other Studies into the Agency and Identity of the Galatians in the Hellenistic and Early-Roman Periods (Leuven, forthcoming), 97-144. Xerxes' great size is already stressed by Herodotus ( $\mu \varepsilon \gamma \alpha \dot{\alpha} \theta \varepsilon o \varsigma, 7.187 .2)$ : Hornblower (n. 1), 489.

${ }^{67}$ Anonymi in Aristotelis Artem rhetoricam III/3 (fol. 55r 16-17), CAG XII/2 174.24-6. See Berra (n. 39), 272-3 and 315 (Annexe 1.2) for further cases of possible Byzantine confusion between the different Lycophrons.

68 On the South Italian Alexandra, see Hornblower (n. 1), 47-9; id., Lykophron's Alexandra, Rome, and the Hellenistic World (Oxford, 2018). The association of the sophistic Lycophron and Gorgias' Sicilian school goes back at least to E. Zeller (transl. S.F. Alleyne), A History of Greek Philosophy: From the Earliest Period to the Time of Socrates (London, 1881), 2.425-6 with n. 3; now, though, see the caution of Giombini (n. 43). 